\title{
Faculty and Work: Stress or Performance?
}

\author{
Mihaela CRET $\mathbf{U}^{1}$ \\ Ana Alexandra GORA ${ }^{2}$
}

\begin{abstract}
Over time, the participation of young people in education and the labor market has been pursued and it has been shown that working during college leads to an increase in employment opportunities after the completion of studies, and in the current context of society the student status is no longer sufficient. The interpretation of this dual role of student-employee has become an important source of stress. In this regard, this paper aims to identify the links between different factors of stress at work and faculty and the work and academic performance obtained by students.

The paper is based on a research conducted at the level of 115 students from The Bucharest University of Economic Studies and multiple linear regression analyses were used to determine the links between different stressors and performance. The main results illustrate the influence between workplace stressors and workplace performance, between academic stressors and academic performance, between workplace stressors and academic performance and between academic stressors and workplace performance. Furthermore, the results suggest that this study can make some practical contributions both to students and to universities and managers.
\end{abstract}

Keywords: academic performance, academic stressors, employees, multiple linear regression, students, workplace performance, workplace stressors.

JEL classification: C21, E24, F19, I23

DOI: $10.24818 /$ RMCI.2019.4.409

\section{Introduction}

In contemporary society, with the increase of the technical, industrial and informational progress, in which the multilateral and multicultural development of the human being is a necessity, the student status is not sufficient. Since the college period, many students are forced to get a job for various reasons: payment of studies, the demands of employers to obtain as much professional experience, the desire of the students to put into practice the theoretical knowledge or the desire to become financially independent. The need for some and the pleasure of others to interpret the dual role of student-employee is an important source of stress. Therefore, according to Saqib and Rehman (2018), stress can be considered as a major source of problems

1 Mihaela Crețu, The Bucharest University of Economic Studies, Romania, mihaela.cretu.98 @gmail.com.

2 Ana Alexandra Gora, The Bucharest University of Economic Studies, Romania, anaalexandra.gora@gmail.com 
that students face during academic studies when they are trying to achieve future academic achievements.

Organizational stress is today an increasingly widespread phenomenon, being declared the disease of the 21 st century. Organizations, wishing to adapt to the competitive market in a relatively short time, are engaged on an unstable road, which endangers both the physical and mental health of the employees, as well as its results characterized by lack of motivation, absenteeism, resignation, disruption of the flow production, all of which generate costs.

The specialized literature presents a series of researches that address the complex problem of organizational stress and its implications on workplace performance. On the one hand, Zlate (2007) says that even at a low level of stress, performance is undermined and there is no evidence of an increase in initial performance. On the other hand, Jamal (1984) considers that the relationship between stress level and performance level is curvilinear. Thus, for a start, gradual but slight increases in stress are associated with increased performance, but from a certain level, additional increases in stress lead to decreased performance.

Although there is a wide range of papers in the field of occupational stress and its influence on work performance, this problem has not been studied from the double perspective of the employed student. In this regard, the present paper aims to determine the influence of different workplace stressors on workplace performance and the impact of academic stressors on academic performance. Furthermore, the paper also aims to investigate whether there are links between workplace stressors and academic performance and between academic stressors and workplace performance.

This research begins with an analysis of the literature and presents the particularities of the concept of stress, the effects of organizational stress and the links between stress and performance identified in other studies relevant to the analyzed topic. The research methodology is presented below, the data are analyzed and the results obtained are illustrated. Finally, the paper presents the conclusions of the analysis carried out and also the limitations of the research and the future directions are highlighted.

\section{Theoretical Framework}

\subsection{Stress - conceptual delimitations and determinants}

As Caramete (2002) argues, the term stress comes from the English word "stress" and circumscribes a series of similar nouns as meaning: intense effort, pressure or tension. This tension is caused by the external stimuli of the body and is the result of the exchange between the environment and the individual. According to Caramete (2002), the term stress was launched by Canadian scientist Hans Selye who defines stress as a non-specific reaction of the body to any request. Cravet (2014) defines stress as an individual's reaction or response to situations in which 
he is unable to meet the requirements. It is diffuse and difficult to detect, but its accumulation leads to psychic and social problems (Cravet, 2014).

When we refer to existing stress within organizations, we use the term occupational stress or organizational stress. In this sense, organizational stress can be defined as an emotional, behavioral, cognitive and physiological reaction to the aggressive and harmful aspects of the job-specific, the relationships at work, the working environment, the organizational climate, the role conflict, the role ambiguity, development opportunities, as well as the work-family relationship (Belostecinic \& et al., 2010).

In the definition of occupational stress there are several meanings, as follows (Craveț, 2014): (1) stimulus that acts on the person; (2) non-specific response of the human body to any stimulus; (3) that characteristic of the organization that threatens the employee; (4) result of the negotiation between the demands or pressures of the environment and the hierarchy of the individual goals; and (5) the cognitive, conceptual and physiological effort to reduce or tolerate the internal and external demands that exceed the real or imaginary resources of the employee.

At the base of the emergence of organizational stress are two central agents of a psychological nature (Belostecinic \& et al., 2010):

- Role conflict - occurs when an employee, who occupies a certain position, is subjected to unacceptable, contradictory and incompatible requests between them. Often, the person in question is in the middle, between manager and co-workers, which leads to conflict situations.

- Role ambiguity - is determined by the lack or insufficiency of clear and timely information necessary for the correct resolution of tasks. Thus, the person who faces this situation does not know exactly the objectives, tasks, performances required as well as the evaluation, control and motivation criteria.

Over time, the specialty literature has identified several stressors that affect the employees of an organization. They can be grouped as follows:

- Organizational stress factors - as Caramete (2002) argues, stress is not only limited to the environment within the organization, but we can easily identify a multitude of external factors that have a major impact on the individual, such as: changes in society, family environment, economic and political instability in society, inflation, social class (Caramete, 2002). Moreover, in addition to the potential stressors, which compete outside the organization, other factors that belong to the organization themselves and which can be divided in the following directions have been identified (Grigorievici, 2008): organizational measures (arbitrary reviews of professional performance, inequities to payments); processes (poor communication, ambiguous objectives); structures (absence of participation in decision making, reduced possibilities for advancement); content of work (complexity of work, incorrect distribution of tasks); working conditions (excessive noise, internal crowding).

- Group stressors - the professional group is a potential source of stress, and its main stressors are (Caramete, 2002): lack of cohesion at the group level

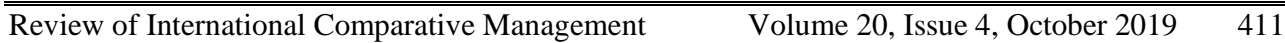


(any isolation of an employee due to conflict causes can generate a state of stress), absence of social support (the individual is influenced by the support of the group members), conflicts between individuals or between groups (are sources of stress associated with the incompatibility of the individual with the group) and communication problems.

- Individual stressors - regarding the factors that depend on the employee, they sum up all the personal problems, as well as the specific characteristics of the employee. In this sense, Grigorievici (2008) identifies the following risk factors that can be sources of stress at work (Grigorievici, 2008): (1) organizational culture and how stress is viewed in the respective environment; (2) the totality of the requirements to which the employees are subjected, respectively if they have too little or too much work, the degree of exposure to physical risks, the contact with the dangerous chemicals; (3) vocational training to provide all employees with the knowledge and qualifications required to perform the tasks; (4) support from the collective and management for integration into work; (5) the social relations built in the workplace, including the existence or absence of moral harassment and (6) the existence or absence of conflicts.

\subsection{The effects of organizational stress}

Stress, as presented in the first chapter, can have both positive and negative connotations. In the organizational context, a medium level of stress is beneficial for motivating the employees, but excessive stress can become pathological. Thus, the effects of stress can be divided into three main groups (Grigorievici, 2008):

- the first group includes the psychological symptoms of stress, among which we find the feeling of dissatisfaction or dissatisfaction that can be manifested in different forms such as depression, fatigue, illness, loss of selfconfidence, instability, apathy, aggression, nervousness, feeling lonely or anxiety;

- the second group includes all the physiological symptoms of stress, including the increased risk of cardiovascular disease, chronic headaches, increased blood sugar, pupil dilation or increased blood pressure;

- the last group combines behavioral symptoms such as alcohol abuse, coffee abuse, excessive smoking, impulsive behavior, low productivity, absenteeism, isolation, reduced responsibility and loyalty to the organization, all of which affect the quality and quantity of work performed.

Pitariu, Radu and Chraif (2009) as well as Chraif and Aniței (2011) underlined the strong link between skills, stressors and the level of performance achieved by employees in the workplace. At the same time, psychologists Landy and Conte (2009) highlighted how performance is influenced by the specificity of the organization, but also how performance is directly related to the company's objectives and the productivity achieved by it.

In this sense, theories that analyze the effects of stress on performance are divided, starting from the assumption that people are different, and they react differently to stressful situations in the workplace. On the one hand, some 
researchers consider that the relationship between stress level and performance level is curvilinear (Jamal, 1984). Thus, for a start, the gradual but slight increases of stress are associated with the increase of the performance, but from a certain level, the additional increases of the stress lead to the decrease of the performances. But there is another point of view, promoted by the psychology doctor Zlate (2007) quoting Greenberg and Baron (1990) who states that even at a low level of stress, the performance is undermined and there is no evidence of increased initial performance. To support this view, a number of arguments have been made, among which (Zlate, 2007): prolonged exposure to stress, even at low levels, adversely affects performance; relatively mild stress leads to the disorganization of the individual and causes him to focus more on the negative emotions produced by stress, than on the tasks he has to perform.

According to Jamal (1984) performance can be adversely affected by several factors, including role conflict, due to confusion created at the level of role signals that lead to increased role difficulty. Also, performance might be affected by role ambiguity because role overload leads to physical, emotional, and cognitive exhaustion, which subsequently contributes to deteriorating performance quality (Jamal, 1984).

From the medical, psychological or behavioral consequences of stress, we will analyze the economic and social ones. Stress, as we have shown in previous chapters, participates in diminishing performance and productivity in the workplace, thus affecting the evolution of the organization and the economy as a whole. Organizations, wishing to adapt to the competitive market in a relatively short time, are engaged on an unstable road, which endangers both the physical and mental health of employees, as well as the results of the company characterized by lack of motivation, absenteeism, resignation, disruption of flow. production, recruitment and training of new employees, all of which generate costs.

The European Union estimated the economic cost of stress in 2016 as having a value of 617 billion euros annually. The total cost includes absenteeism costs ( 272 billion euros), productivity losses ( 242 billion euros), health care costs (63 billion euros) and social assistance costs in the form of payments for social security payments disability (39 billion euros) (EU-OSHA, 2014).

The social cost of stress includes all the expenses for the recovery and maintenance of the personnel. Therefore, the existence of occupational diseases has the effect of reducing the life of the personnel, diminishing the capacity of work, all leading to the carrying out of social expenses for the recovery of the personnel or for his retirement (Saunier, 2007).

\subsection{Students on the labor market}

Employment during college has become an important thing today, which has serious implications for students' academic performance as well as their motivation to study. On the one hand, it enriches the baggage of practical knowledge but also 
increases the probability of dropping out, especially for those who work in their first year of college, as well as the probability of prolonging their studies (Mirică, 2018).

For a broader understanding of the phenomenon of work-study and its implications, a series of statistical data are analyzed through this paper. For instance, in 2016, 54\% of young people in the European Union (EU) did not work at all during their studies. The highest rate of non-working students was in Romania (91\%), followed by Greece (78\%), Bulgaria (77\%) and Spain (74\%), while the lowest rates were in Finland (8\%) and Sweden (17\%). In the EU, the rate of young people who do not work during studies has decreased from 65\% in 2009 to 54\% in 2016 (Eurostat, 2018).

In the EU, the unemployment rate among young people without work experience during education was $15.7 \%$ in 2016, while for people with work experience outside the curriculum it was $8.1 \%$. In Romania, the unemployment rate for students who worked only outside the curriculum was $7.1 \%$, and for those who learned based on it was $10 \%$. Therefore, work during studies increases the chance of finding a job later (Eurostat, 2018).

In the context of the EU 2020 Strategy of the European Commission (European Commission, 2010) which has several objectives for participation in education and the labor market for young people: at least $40 \%$ of young people must have a tertiary education, the employment rate of people aged 20-34, within 3 years of graduation, should be at least $82 \%$, we can say that increasing the level of education of young people will lead to an increase in the percentage of young people working during studies and it becomes even more necessary to find effective ways for Romania to align with the European trend and strategic objectives.

\subsection{The link between stress and performance in other researchers}

Considering the literature, other studies relevant to the subject addressed through this paper have been identified, researches that analyze the link between different stressors and performance. Thus, regarding the relationship stress and performance at work, Nyangahu and Bula (2015) highlight by the results of their study that a high level of stress negatively affects the quality of the work outcomes and the performance of the employees while the low level of stress has a positive impact on the performance and the quality of the employees' work results. Also in this regard, Imtiaz and Ahmad (2009) show through their study that different stressors (such as rigidity in organizational structure, monetary reward, administrator support, personal issues) are significantly negatively correlated with workplace performance. Furthermore, Fonkeng (2018) discovers through their research conducted among 80 employees of a Micro Finance Institution that the stressors that were identified at this job negatively affect the performance of the employees. In this sense, through this study, it can be emphasized that employees need not be stressed to perform well (Fonkeng, 2018).

Regarding the link between academic stressors and academic performance, Elias, Ping and Abdullah (2011) conducted a study among 376 undergraduate students with the objective of researching the relationship between stress and academic 
achievement. The results of their study show that stress is significantly correlated with students 'academic performance, with a negative but weak relationship between students' stress level and their performance. Saqib and Rehman (2018) follow through their research to highlight what type of stress is related to performance, evaluate the impact of stress on academic performance and differentiate the impact of stress on performance according to the students' gender. In this respect, the results of their study conducted on 225 respondents demonstrate that there are no differences in gender impact of stress, the academic performance of students being affected by the same stressors (the stressors in this research being: teacher stress, family pressure, academic results, future stress). Moreover, the results of the study show that the impact of stress on students' academic performance is statistically significant (Saqib \& Rehman, 2018).

Also in this regard, Rafidah et al. (2009) investigate the relationship between perceived stress, stress factors and academic performance among 154 students. Among the results of their research, they discover that there is a significant correlation between the perceived stress level at the end of the semester and the students` academic performance, a negative but rather weak correlation. More specifically, the results show that when the stress level will be higher, academic performance will be lower but the perceived stress level by the respondents was not so high that students would not cope with academic activities (Rafidah et al., 2009). Furthermore, analyzing the relationship between stress and academic performance at the level of 584 students Oketch-Oboth and Okunya (2018) show that most students report a moderate to high level of stress, demonstrating that the relationship between stress and academic performance is statistically significative, the higher the stress level, the lower the performance. Moreover, they investigate the relationship between stress level and academic performance according to gender, age, course, year of study, etc., obtaining a series of statistically significant results between the two investigated variables (Oketch - Oboth \& Okunya, 2018).

In this respect, starting from the theoretical support presented in the previous chapters and from the results identified in other studies related to the analyzed subject, the following research hypotheses were formulated:

Hypothesis 1 (H1): Workplace stressors negatively influence workplace performance.

Hypothesis 2 (H2): Academic stressors negatively influence academic performance.

On the other hand, data provided by Eurostat (Eurostat, 2018) shows that working during college increases the chances of employment of students in the labor market, after the completion of studies and that the number of students employed from year to year is increasing. Moreover, the EU 2020 Strategy (European Commission, 2010) aims to increase the participation of young people in education and in the labor market. Thus, it can be seen that it is desired to create a balance between the faculty and the workplace and it is expected that the students, during the study period, will be actively involved in both processes. In this sense, starting from the interdependencies between the faculty and the labor market, and in the context of this research, it might also be useful to carry out an analysis to identify the connections and the impact that 
workplace stressors can have on the academic performances obtained by students in the faculty but also, as well as, the influence of the academic stressors on the workplace performance. In this regard, two further research hypotheses were formulated:

Hypothesis 3 (H3): Workplace stressors negatively influence academic performance.

Hypothesis 4 (H4): Academic stressors negatively influence workplace performance.

Synthesizing, based on the theoretical discussions and the research hypotheses, the following research model were obtained (Figure 1):

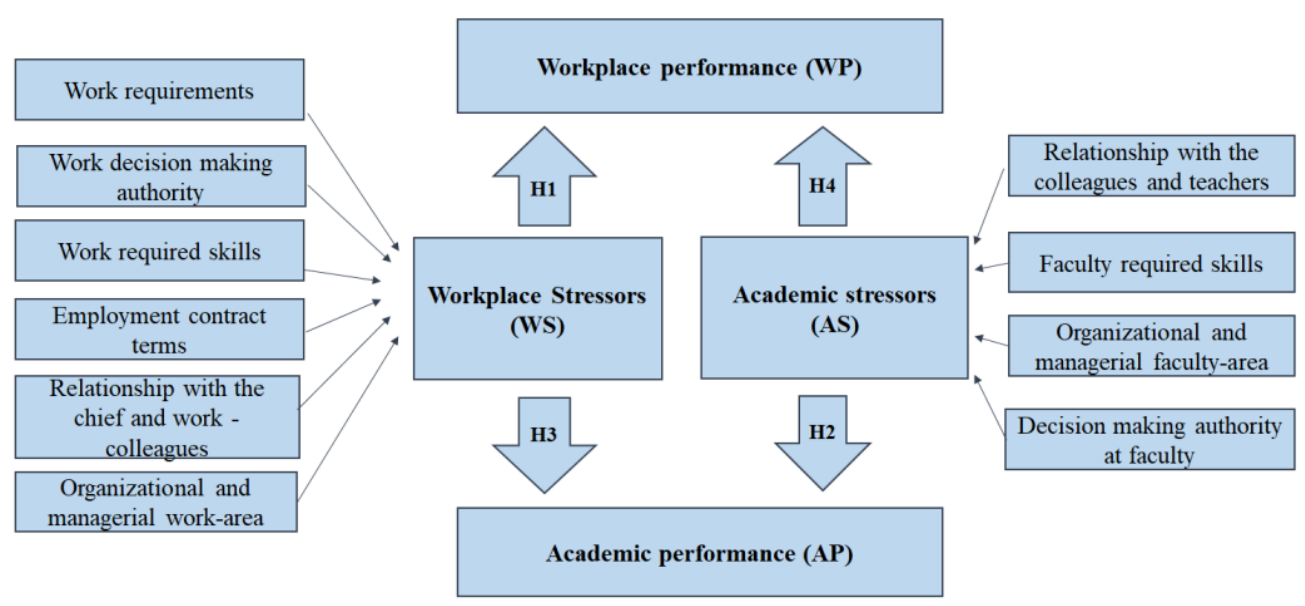

Figure 1. Research Model

Source: Created by authors

\section{Research methodology}

\subsection{Data collection}

Regarding the way of evaluating the stress - performance phenomenon and the data collection, a questionnaire survey was conducted in the present research. For this purpose, a questionnaire was developed using the Google Forms platform, taking into account the topic of the study and the specific socio-professional of the students (students who are also employed).

The questionnaire was composed of 65 closed questions structured in such a way for allowing the identification of the targeted research variables, namely: workplace stressors, academic stressors, the level of workplace performance and the academic performance, as illustrated in Table 1. 
Table 1. Research Variable

\begin{tabular}{|c|c|c|}
\hline Factors/Stressors & Items & Variables \\
\hline \multicolumn{3}{|c|}{ Workplace Stressors (WS) } \\
\hline Work requirements & 4 & WR 1 - WR4 \\
\hline Work decision making authority & 4 & WDMA1 - WDMA4 \\
\hline Work required skills & 4 & WRS1 - WRS4 \\
\hline Employment contract terms & 4 & ECT1 - ECT4 \\
\hline Relationship with the chief and work - colleagues & 4 & RCCW1 - RCCW4 \\
\hline Organizational and managerial work-area & 4 & OMWS1 - OMWS4 \\
\hline \multicolumn{3}{|l|}{ Academic stressors (AS) } \\
\hline Relationship with the colleagues and teachers & 6 & RCTF1 - RCTF 6 \\
\hline Faculty required skills & 2 & FRS1 - FRS2 \\
\hline Organizational and managerial faculty-area & 11 & OMFS1 - OMFS11 \\
\hline Decision making authority at faculty & 1 & DMAF1 \\
\hline Workplace performance (WP) & 7 & WP1- WP7 \\
\hline Academic performance (AP) & 6 & AP1 - AP6 \\
\hline
\end{tabular}

Source: Created by authors based on questionnaire

The questionnaire used to collect data was structured in three parts. The first part contained 8 questions regarding the demographic and social characteristics of the respondents such as age, gender, study programs (bachelor/master/doctoral study), age of study, the form of financing, etc. The second part of the questionnaire consisted of 30 questions referring to the first two variables of the research, the stress factors and the performance within the respondents' workplace. The third part consisted of 27 questions regarding the second category of research variables, namely stressors and faculty performance. To obtain a data set as accurate as possible, a Likert scale with five values was used, where 1 represented "Total disagreement" and 5 "Total agreement". Moreover, in order to collect data that express best the opinion of the respondents regarding the questions asked by the questionnaire, and to test the attention paid by them in completing the questionnaire, a series of questions with inverted meaning were formulated. Subsequently, in order to prepare the data for the analysis, the results have been modified so that value 1 shows a low level of stress on the respondent or a low level of performance and value 5 indicates a stress factor with a high influence or a high performance.

\subsection{Population and research sample}

The population-based on which the analysis is performed is represented by the students from The Bucharest University of Economic Studies (ASE) who are also employed. Non-probabilistic sampling method was used because no such database was constructed so far, which to includes information regarding the employement status of the population analyzed. Thus, from the sample of 115 employed students, $63.5 \%$ were enrolled in the bachelor's programs, $26.1 \%$ in the masters programs and $10.4 \%$ in the doctoral programs. The respondents were $61.7 \%$ women and $38.3 \%$ men. Regarding 
the form of student financing, $62.6 \%$ of them were funded from the State budget, while the rest of $31.3 \%$ were tax - funded. Moreover, the marital status of the students surveyed indicates that $85.2 \%$ are not married and $12.2 \%$ are married. Of the 115 respondents, $39.13 \%$ live in rent, $33.04 \%$ have their place or they live with their families and the remaining $27.83 \%$ live in a student campus.

\subsection{Procedure}

The questionnaire was made with the help of the Google Forms platform and the distribution of the questionnaire was done in the online environment through socialization platforms and through the direct addressing of the persons inside The Bucharest University of Economic Studies. The questionnaire was preceded by a preamble through which the respondents are informed about the purpose of the research and the fact that the answers offered will be used for scientific purposes only. The respondents were also informed about the confidentiality of the data and the fact that the completion of the questionnaire is voluntary.

The results of this survey were evaluated using statistical methods. Therefore, Statistical Package for the Social Sciences (SPSS) software was used to quantify data and test hypotheses. In this regard, a series of descriptive statistics were made, the Cronbach`s Alfa coefficient was computed and various correlation coefficients between variables were calculated prior to the analysis. Subsequently, multiple linear regression analysis was used to determine the influence of stressors at work and faculty, consider independent variables on performance achieved both at work and at faculty, considered as dependent variables.

\section{Results and discussions}

\subsection{Preliminary analysis}

Before testing the formulated research hypotheses, a series of descriptive statistics were made using the SPSS statistics program. Table 2 presents these results, together with the Cronbach`s Alpha reliability coefficient calculated for each group of variables and the correlation coefficients between them.

Table 2. Results of preliminary analysis

\begin{tabular}{|c|c|c|c|c|c|c|c|c|}
\hline \multirow{2}{*}{ Categories } & \multirow{2}{*}{ Stressors } & \multirow{2}{*}{ M } & \multirow{2}{*}{ SD } & \multirow{2}{*}{$\mathbf{V}$} & \multirow{2}{*}{ Items } & \multirow{2}{*}{$\begin{array}{l}\text { Cronbach's } \\
\text { Alpha }\end{array}$} & \multicolumn{2}{|c|}{ Correlations } \\
\hline & & & & & & & $\begin{array}{c}\text { Workplace } \\
\text { performance }\end{array}$ & $\begin{array}{c}\text { Academic } \\
\text { performance }\end{array}$ \\
\hline \multirow{4}{*}{$\begin{array}{l}\text { Workplace } \\
\text { Stressors } \\
\text { (WS) }\end{array}$} & $\begin{array}{l}\text { Work } \\
\text { requirements }\end{array}$ & 3.388 & 1.001 & 1.002 & 3 & 0.695 & 0.136 & 0.107 \\
\hline & $\begin{array}{l}\text { Work decision } \\
\text { making authority }\end{array}$ & 2.948 & 0.968 & 0.937 & 4 & 0.704 & $-0.312 * *$ & -0.141 \\
\hline & $\begin{array}{l}\begin{array}{l}\text { Work required } \\
\text { skills }\end{array} \\
\end{array}$ & 2.061 & 0.868 & 0.754 & 3 & 0.666 & $-0.540 * *$ & $-0.217 *$ \\
\hline & \begin{tabular}{|l|} 
Employment \\
contract terms
\end{tabular} & 2.424 & 0.860 & 0.740 & 4 & 0.639 & $-0.443 * *$ & $-0.270 * *$ \\
\hline
\end{tabular}

418 Volume 20, Issue 4, October 2019 Review of International Comparative Management 


\begin{tabular}{|c|c|c|c|c|c|c|c|c|}
\hline \multirow{4}{*}{ Categories } & \multirow{2}{*}{ Stressors } & \multirow{2}{*}{ M } & \multirow{2}{*}{ SD } & \multirow{2}{*}{$\mathbf{V}$} & \multirow{2}{*}{ Items } & \multirow{2}{*}{$\begin{array}{c}\text { Cronbach's } \\
\text { Alpha }\end{array}$} & \multicolumn{2}{|c|}{ Correlations } \\
\hline & & & & & & & $\begin{array}{c}\text { Workplace } \\
\text { performance }\end{array}$ & $\begin{array}{c}\text { Academic } \\
\text { performance }\end{array}$ \\
\hline & $\begin{array}{l}\text { Relationship with } \\
\text { the chief and } \\
\text { work-colleagues }\end{array}$ & 2.429 & 0.882 & 0.777 & 3 & 0.74 & $-0.710 * *$ & $-0.277 * *$ \\
\hline & $\begin{array}{l}\text { Organizational } \\
\text { and managerial } \\
\text { work-area }\end{array}$ & 2.658 & 0.973 & 0.946 & 3 & 0.642 & $-0.347 * *$ & 0.058 \\
\hline \multirow{4}{*}{$\begin{array}{l}\text { Academic } \\
\text { stressors } \\
\text { (AS) }\end{array}$} & $\begin{array}{l}\text { Relationship with } \\
\text { the colleagues and } \\
\text { teachers }\end{array}$ & 3.403 & 0.932 & 0.868 & 3 & 0.685 & -0.022 & -0.078 \\
\hline & \begin{tabular}{|l|}
$\begin{array}{l}\text { Faculty required } \\
\text { skills }\end{array}$ \\
\end{tabular} & 2.717 & 0.991 & 0.983 & 2 & 0.71 & $-0.204 *$ & $-0.427 * *$ \\
\hline & $\begin{array}{l}\text { Organizational } \\
\text { and managerial } \\
\text { faculty-area }\end{array}$ & 3.047 & 0.626 & 0.392 & 11 & 0.747 & $-0.211 *$ & $-0.316^{* *}$ \\
\hline & $\begin{array}{l}\text { Decision making } \\
\text { authority at } \\
\text { faculty }\end{array}$ & 3.426 & 1.085 & 1.177 & 1 & - & 0.087 & 0.181 \\
\hline \multicolumn{2}{|c|}{ Workplace performance (WP) } & 3.766 & 0.735 & 0.540 & 7 & 0.847 & - & $0.320 * *$ \\
\hline \multicolumn{2}{|c|}{ Academic performance (AP) } & 3.277 & 0.766 & 0.587 & 6 & 0.814 & $0.320 * *$ & - \\
\hline
\end{tabular}

Source: survey results computed with IBM SPSS

Note: $*$ - $\mathrm{p}<0.05 ; * *-\mathrm{p}<0.01 ;$ M-Mean, SD - Standard Deviation; V - Variance

As mentioned above, before testing the formulated research hypotheses, it was performed an analysis of the data to be processed, the Cronbach`s Alpha coefficient was computed. This coefficient is a measure of internal consistency and illustrates how closely related a set of items are as a group. Generally, the Cronbach`s Alpha takes value within the 0-1 interval. However, to be an acceptable reliability coefficient, the Cronbach`s Alpha value must be above the generally accepted threshold of 0.7 (Opariuc-Dan, 2011; Popa et al., 2018; Popa \& Ștefan, 2019). In the present paper, this coefficient was computed with the help of the SPSS statistics software and its values are illustrated in Table 2.

To obtain the Cronbach`s Alpha reliability coefficient values above 0.7 or very close to this limit some scales were removed. In this respect, one item was excluded from the following variables: "Work requirements", "Work required skills", "Relationship with the chief and work-colleagues", "Organizational and managerial work-area" and 3 items for the "Relationship with the colleagues and teachers" variable.

Following the calculation of the Cronbach`s Alpha coefficient, some descriptive statistics were calculated regarding the variables used in the present research. Analyzing the results obtained in Table 2 it can be observed that the most intense stress factor felt by the students respondents at the workplace is represented by the variable "Work requirements" with a mean (M) of 3.388 and a standard deviation (SD) of 1.001, followed by the stressor "Work decision making authority" ( $\mathrm{M}=2.984$; $\mathrm{SD}=0.968)$. Regarding the academic stressors, it can be stated that the most stressful factors felt by the respondents are "Decision making authority at faculty" $(\mathrm{M}=3.426$; 
$\mathrm{SD}=1.085)$ and "Relationship with the colleagues and teachers" $(\mathrm{M}=3.403$; $\mathrm{SD}=0.932$ ).

The correlation coefficients between the group of variables are illustrated in Table 2. In this regard, it can be observed that out of the 6 independent variables in the category of workplace stressors, 5 variables indicate a statistically negative and significant correlation with the dependent variable of workplace performance (their associated $p$ is smaller than 0.05). Concerning the correlations existing between the group of variables academic stressors and workplace performance, it can be observed that 2 significant negative correlations were obtained between them. Moreover, analyzing the correlations between workplace stressors and academic performance, it can be stated that there are only 3 variables independent out of the 6 that have a statistically significant correlation with the dependent variable, these correlations being negative. The last correlations in Table 2 that are analyzed represent the correlations between the variables academic stressors and academic performance and two significant negative correlations are obtained between the dependent variable academic performance and the independent variables "Faculty required skills" and "Organizational and managerial faculty-area".

\subsection{Testing Research Hypotheses}

Subsequent to the preliminary analysis, the hypotheses were tested. Thus, to test the research hypotheses, multiple linear regression analyses were used, as presented in the methodology section. In this regard, both workplace stressors and the academic stressors were considered independent variables and the aim was to determine their influence on the workplace performance and academic performance, as dependent variables.

Before performing the regression analyses the variance inflation factor (VIF) to diagnose the collinearity statistic was computed. This coefficient measures the extent of a correlation between one predictor and the other predictors in a model to determine the existence of multicollinearity. The values obtained for VIF are within the accepted limits, VIF < 10 (Gujarati, 2004; Robinson and Schumacker, 2009), as can be seen from Tables 3-6, which indicates that there is no multicollinearity between the independent variables. Given this result, multiple linear regression analysis can be performed. In this research, the result of multiple linear regression was tested based on a statistically significant level of 0.05 .

The results of the multiple linear regression model between the workplace stressors and workplace performance are computed in Table 3. 
Table 3. Multiple linear regression model between workplace stressors and workplace performance

\begin{tabular}{|c|c|c|c|c|c|c|c|c|}
\hline \multirow{2}{*}{ Variables } & \multirow{2}{*}{ B } & \multirow{2}{*}{$\beta$} & \multirow{2}{*}{$\mathbf{t}$} & \multirow{2}{*}{$\mathbf{p}$} & \multicolumn{2}{|c|}{ CI 95\% } & \multicolumn{2}{|c|}{ Collinearity Statistics } \\
\hline & & & & & Lower & Upper & Tolerance & VIF \\
\hline Constant & 5.661 & & 24.743 & 0.000 & 5.207 & 6.114 & & \\
\hline $\begin{array}{l}\text { Work requirements } \\
\text { (H1a-) }\end{array}$ & 0.089 & 0.122 & 1.751 & 0.083 & -0.012 & 0.191 & 0.629 & 1.59 \\
\hline \begin{tabular}{|l|} 
Work decision \\
making authority \\
(H1b-)
\end{tabular} & 0.041 & 0.054 & 0.772 & 0.442 & -0.064 & 0.146 & 0.626 & 1.597 \\
\hline $\begin{array}{l}\text { Work required } \\
\text { skills (H1c-) }\end{array}$ & -0.297 & -0.350 & -5.301 & 0.000 & -0.408 & -0.186 & 0.695 & 1.439 \\
\hline $\begin{array}{l}\text { Employment } \\
\text { contract terms } \\
\text { (H1d-) }\end{array}$ & -0.115 & -0.134 & -1.850 & 0.067 & -0.237 & 0.008 & 0.579 & 1.728 \\
\hline $\begin{array}{l}\text { Relationship with } \\
\text { the chief and work } \\
\text { - colleagues } \\
\text { (H1e-) }\end{array}$ & -0.408 & -0.490 & -6.540 & 0.000 & -0.532 & -0.285 & 0.541 & 1.847 \\
\hline $\begin{array}{l}\text { Organizational and } \\
\text { managerial work- } \\
\text { area (H1f-) }\end{array}$ & -0.164 & -0.217 & -3.509 & 0.001 & -0.257 & -0.071 & 0.793 & 1.262 \\
\hline
\end{tabular}

Source: authors with IBM SPSS

Note: B - Unstandardized Coefficient; $\beta$-Standardized Coefficient; $\mathrm{t}-\mathrm{t}$ - Value ; $\mathrm{p}$ - probability value; CI 95\% - 95\% Confidence Intervals for B; VIF - variance inflation factor; R2= the coefficient of determination; F-F statistic

The regression model described by Table 3 represents a valid one due to the fact that Significance $F$ has the associated probability $(p)$ of 0.000 . The coefficient of determination $\left(R^{2}=0.672\right)$ illustrates that $67.2 \%$ of the variability of the dependent variable depends on the independent variables. The intercept (Constant) represents the average workplace performance if no other regressors would have an influence. Analyzing also the independent variables, it could be observed that the workplace performance is negatively and significantly influenced by the following regressors: "Relationship with the chief and work - colleagues (H1e-)" $(\beta=-0.490, p=0.000)$, "Work required skills (H1c-)" $(\beta=-0.350, p=0.000)$ and "Organizational and managerial work -area (H1f-)" $(\beta=-0.217, p=0.001)$. The other regressors do not have a significant influence on the model, because their $p$ values are higher than 0.05 . Thus, two of these independent variables that are not statistically significant have a positive influence on the dependent variable workplace performance: "Work requirements (H1a-)" $(\beta=0.122, p=0.083)$ and "Work decision making authority (H1b-)" ( $\beta=0.054, p=0.442)$, while one of the independent variables has a negative influence: "Employment contract terms (H1d-)" $(\beta=-0.134, p=0.067)$.

Table 4 illustrate the results performed by applying the multiple linear regression model between academic stressors, as independent variables, and academic performance, considered dependent variable. 
Table 4. Multiple linear regression model between academic stressors and academic performance

\begin{tabular}{|c|c|c|c|c|c|c|c|c|}
\hline \multirow{2}{*}{ Variables } & \multirow{2}{*}{ B } & \multirow{2}{*}{$\beta$} & \multirow{2}{*}{$\mathbf{t}$} & \multirow{2}{*}{$\mathbf{p}$} & \multicolumn{2}{|c|}{ CI 95\% } & \multicolumn{2}{|c|}{ Collinearity Statistics } \\
\hline & & & & & Lower & Upper & Tolerance & VIF \\
\hline Constant & 4.239 & & 12.277 & 0.000 & 3.555 & 4.923 & & \\
\hline $\begin{array}{l}\text { Relationship with } \\
\text { the colleagues and } \\
\text { teachers (H2a-) }\end{array}$ & 0.009 & 0.011 & 0.111 & 0.912 & -0.156 & 0.175 & 0.635 & 1.575 \\
\hline $\begin{array}{l}\begin{array}{l}\text { Faculty required } \\
\text { skills (H2b-) }\end{array} \\
\end{array}$ & -0.282 & -0.365 & -4.029 & 0.000 & -0.421 & -0.144 & 0.796 & 1.256 \\
\hline $\begin{array}{l}\text { Organizational and } \\
\text { managerial faculty- } \\
\text { area (H2c-) }\end{array}$ & -0.291 & -0.238 & -2.170 & 0.032 & -0.557 & -0.025 & 0.545 & 1.835 \\
\hline $\begin{array}{l}\text { Decision making } \\
\text { authority at faculty } \\
(\mathrm{H} 2 \mathrm{~d}-)\end{array}$ & 0.193 & 0.273 & 3.257 & 0.001 & 0.076 & 0.310 & 0.931 & 1.074 \\
\hline
\end{tabular}

Source: authors with IBM SPSS

Note: B - Unstandardized Coefficient; $\beta$ - Standardized Coefficient; $\mathrm{t}$ - $\mathrm{t}$ - Value ; $\mathrm{p}$ probability value; CI 95\% - 95\% Confidence Intervals for B; VIF - variance inflation factor; $\mathrm{R}^{2}=$ the coefficient of determination; $\mathrm{F}-\mathrm{F}$ statistic

Analyzing the results presented in Table 4 it can be observed that the $F$ value $=10.682$ is statistically significant because the probability $(p)$ associated with this value is $p=0.000$ and is lower than the threshold of 0.05 . The value of the coefficient of determination $\left(R^{2}=0.280\right)$ shows that approximatively $28 \%$ of the variance in academic performance depends on the independent variables. The intercept (Constant) represents the average academic performance if no other regressors would have an influence. Furthermore, the $p$ values associated with the independent variables related to the stressors of the faculty that influence the academic performance indicate a value less than 0.05 for 3 of 4 variables, so statistically significant for most variables, except for the variable "Relationship with the colleagues and teachers (H2a-)" with a associated probability $(p)$ of 0.912 . In this respect it can be concluded that the dependent variable academic performance is negatively and significantly influenced by the following regressors: "Faculty required skills $(\mathrm{H} 2 \mathrm{~b}-)$ " $(\beta=-0.365, p=0.000)$ and "Organizational and managerial faculty-area (H2c-)" ( $\beta=-0.238, p=0.032)$, and this is positively and significantly influenced by the independent variable "Decision making authority at faculty $(\mathrm{H} 2 \mathrm{~d}-)^{\prime \prime}(\beta=0.273, p=0.001)$.

Further, the results of the influence of workplace stressors on academic performance, calculated using multiple linear regression analysis are presented in Table 5. 
Table 5. Multiple linear regression model between workplace stressors and academic performance

\begin{tabular}{|c|c|c|c|c|c|c|c|c|}
\hline \multirow{2}{*}{ Variables } & \multirow{2}{*}{ B } & \multirow{2}{*}{$\beta$} & \multirow{2}{*}{$\mathbf{t}$} & \multirow{2}{*}{$\mathbf{p}$} & \multicolumn{2}{|c|}{ CI 95\% } & \multicolumn{2}{|c|}{ Collinearity Statistics } \\
\hline & & & & & Lower & Upper & Tolerance & VIF \\
\hline Constant & 3.685 & & 9.629 & 0.000 & 2.926 & 4.443 & & \\
\hline $\begin{array}{l}\text { Work } \\
\text { requirements } \\
\text { (H3a -) }\end{array}$ & 0.084 & 0.110 & 0.987 & 0.326 & -0.085 & 0.253 & 0.629 & 1.59 \\
\hline $\begin{array}{l}\text { Work decision } \\
\text { making authority } \\
\text { (H3b-) }\end{array}$ & 0.033 & 0.042 & 0.373 & 0.710 & -0.142 & 0.208 & 0.626 & 1.597 \\
\hline $\begin{array}{l}\text { Work required } \\
\text { skills (H3c-) }\end{array}$ & -0.078 & -0.088 & -0.834 & 0.406 & -0.264 & 0.108 & 0.695 & 1.439 \\
\hline $\begin{array}{l}\text { Employment } \\
\text { contract terms } \\
(\mathrm{H} 3 \mathrm{~d}-)\end{array}$ & -0.238 & -0.267 & -2.298 & 0.024 & -0.443 & -0.033 & 0.579 & 1.728 \\
\hline $\begin{array}{l}\text { Relationship with } \\
\text { the chief and work } \\
\text { - colleagues } \\
\text { (H3e-) }\end{array}$ & -0.155 & -0.178 & -1.485 & 0.141 & -0.362 & 0.052 & 0.541 & 1.847 \\
\hline $\begin{array}{l}\text { Organizational and } \\
\text { managerial work- } \\
\text { area (H3f-) }\end{array}$ & 0.122 & 0.155 & 1.557 & 0.122 & -0.033 & 0.277 & 0.793 & 1.262 \\
\hline
\end{tabular}

Source: authors with IBM SPSS

Note: B - Unstandardized Coefficient; $\beta$-Standardized Coefficient; $\mathrm{t}-\mathrm{t}$ - Value ; $\mathrm{p}$ - probability value; CI 95\% - 95\% Confidence Intervals for B; VIF - variance inflation factor; R2= the coefficient of determination; F-F statistic

The regression model described by Table 5 represents a valid one due to the fact that Significance $F=3.325$ has the associated probability $(p)$ of 0.005 but the value of the coefficient of determination $R^{2}=0.156$ illustrates that only $15.6 \%$ of the variability of the academic performance depends on the independent variables.

Thus, analyzing the results illustrated in Table 5 it can be observed that there is only one independent variable that refers to the stressors at the workplace that represent a good predictor of the dependent variable academic performance. This regressor is "Employment contract terms (H3d-)" and is a good predictor due to the associated probability $(p)$ of 0.024 , this value $\mathrm{p}$ being statistically significant $(p<0.05)$ and having a negative influence on academic performance $(\beta=-0.267)$. The other independent variables influence academic performance, but the results of their influences are not statistically significant. More exactly, the variables "Organizational and managerial work-area (H3f-) "( $\beta=0.155, p=0.122)$, "Work requirements (H3a-)" $(\beta=0.110$, $p=0.326)$ and "Work decision making authority $(\mathrm{H} 3 \mathrm{~b}-)$ " $(\beta=0.042, p=0.373)$ have a positive influence on academic performance while variables "Relationship with the chief and work - colleagues (H3e-)" $(\beta=-0.178, p=0.141)$ and "Work required skills $(\mathrm{H} 3 \mathrm{c}-)^{\prime}(\beta=-0.088, p=0.406)$ negatively affects the dependent variable. 
The last computed multiple linear regression analysis referred to the link between academic stressors and workplace performance and the results are illustrated in Table 6.

Table 6. Multiple linear regression model between academic stressors and workplace performance

\begin{tabular}{|c|c|c|c|c|c|c|c|c|}
\hline \multirow{2}{*}{ Variables } & \multirow{2}{*}{ B } & \multirow{2}{*}{$\beta$} & \multirow{2}{*}{$\mathbf{t}$} & \multirow{2}{*}{$\mathbf{p}$} & \multicolumn{2}{|c|}{ CI 95\% } & \multicolumn{2}{|c|}{ Collinearity Statistics } \\
\hline & & & & & Lower & Upper & Tolerance & VIF \\
\hline Constant & 4.334 & & 11.617 & 0.000 & 3.595 & 5.073 & & \\
\hline $\begin{array}{l}\text { Relationship with } \\
\text { the colleagues and } \\
\text { teachers (H4a -) }\end{array}$ & 0.069 & 0.087 & 0.764 & 0.447 & -0.110 & 0.248 & 0.635 & 1.575 \\
\hline $\begin{array}{l}\begin{array}{l}\text { Faculty required } \\
\text { skills }(\mathrm{H} 4 \mathrm{~b}-)\end{array} \\
\end{array}$ & -0.096 & -0.130 & -1.270 & 0.207 & -0.246 & 0.054 & 0.796 & 1.256 \\
\hline \begin{tabular}{|l|} 
Organizational and \\
managerial \\
faculty-area \\
$(\mathrm{H} 4 \mathrm{c}-)$
\end{tabular} & -0.280 & -0.238 & -1.929 & 0.056 & -0.567 & 0.008 & 0.545 & 1.835 \\
\hline $\begin{array}{l}\text { Decision making } \\
\text { authority at faculty } \\
(\mathrm{H} 4 \mathrm{~d}-)\end{array}$ & 0.091 & 0.134 & 1.420 & 0.158 & -0.036 & 0.218 & 0.931 & 1.074 \\
\hline
\end{tabular}

Source: authors with IBM SPSS

Note: B - Unstandardized Coefficient; $\beta$ - Standardized Coefficient; $\mathrm{t}-\mathrm{t}$ - Value ; $\mathrm{p}$ probability value; CI 95\% - 95\% Confidence Intervals for B; VIF - variance inflation factor; $\mathrm{R}^{2}=$ the coefficient of determination; $\mathrm{F}-\mathrm{F}$ statistic

Analyzing the results presented in Table 6 it can be observed that the regression model represents a valid one according to the $F$-value $=2.599$ and its associated probability $(p)$ of 0.040 , the model being statistically significant. The value $R^{2}=0.086$ indicates that only $8.6 \%$ of the variance in workplace performance depends on the independent variables. Moreover, considering the $p$ values obtained for each independent variable, it can be concluded that in all situations the value of $p$ is above 0.05 , which makes these variables do not have a statistically significant influence on the workplace performance, as a dependent variable.

\section{Conclusions}

As presented in previous chapters, this paper aimed to investigate the influence of workplace stressors on workplace performance and the impact of academic stressors on academic performance. Furthermore, the paper also aims to determine if there are links between workplace stressors and academic performance and between academic stressors and workplace performance. To determine these influences, multiple linear regression analyses were used, with workplace stressors and academic stressors being considered as independent variables, and work and faculty performance being dependent variables. 
Regarding the first two hypotheses of the research, the main results illustrate that regarding the relationship between workplace stressors and workplace performance the latter is negatively and statistically determined by the following independent variables "Relationship with the chief and work - colleagues", "Work required skills" and "Organizational and managerial work -area". Considering the relationship between academic stressors and academic performance it can be stated that the dependent variable academic performance is negatively and significantly influenced by the following regressors: "Faculty required skills" and "Organizational and managerial faculty-area", and this is also positively and significantly influenced by the independent variable "Decision making authority".

The results obtained for testing the other two research hypotheses show that out of the 6 independent variables related to workplace stressors only one, namely "Employment contract terms" has a statistically negative and significant influence on academic performance. Moreover, it can be concluded that the independent variables related to academic stressors do not have a statistically significant influence on workplace performance, as a dependent variable.

The findings obtained through these analyses can have a number of practical implications among students, universities and managers. Thus, this study may be useful to students because it shows them what stressors can influence both academic performance and workplace performance. In this regard, students must set their individual goals both educationally and professionally so that they find a balance between work and faculty and identify the most appropriate ways to reduce their stress at work and college.

For universities, this paper contributes to providing information on the need to raise awareness of the double status of students, student and employee, provided that the demands on the labor market require students to be more prepared in the workplace. Thus, universities must establish their curricula and study programs to support students to be actively involved in both faculty and work. For example, students can be supported by the university by creating a flexible schedule, without breaks between activities, through a service of psychological assistance of students to eliminate the problems caused by stressors.

Also from a practical point of view, this study can be useful for the managers by highlighting the stress factors felt by the students in the workplace and by presenting the influence of these factors on the performance in the workplace. Moreover, knowing the results obtained from the multiple linear regression analysis on the four research hypotheses formulated, managers should offer more flexibility to the students in establishing the program and the way of working.

During this research, a series of research limitations were identified which should be taken into account in the analysis of results and the design of future research. Thus, the first limitation of the research is due to the lack of a database with the students employed by The Bucharest University of Economic Studies, which did not allow the identification of the entire population that could have been part of the research sample. Another limitation was the small number of respondents compared to the total number of students from The Bucharest University of Economic Studies,

Review of International Comparative Management $\quad$ Volume 20, Issue 4, October 2019 425 
which does not allow extrapolation of the results at a national level. To ensure the continuity of this research topic, it would be necessary to carry out new research regarding the stress-performance relationship among a larger number of students to ensure the representativeness of the sample. Moreover, as a future research, an analysis of the stress level depending on the profession or personality dependence could be carried out and one analysis to determine if different stressors have a different influence on the performances according to their level of manifestation.

\section{References}

1. Belostecinic, G., \& et al., 2010. Analele Academiei de Studii Economice din Moldova. Ediția a VIII-a. Chișinău: ASEM Chișinău.

2. Caramete, C., 2002. Studiu privind stresul organizațional și climatul muncii. București: ASE București.

3. Chraif, M., \& Aniței, M., 2011. The impact of economic crisis on occupational stress and counterproductive behavior in a food and beverage restaurant chain from Romania. Procedia -Social and Behavioral Sciences, 30, pp. 2644-2650. doi.10.1016/j.sbspro.2011.10.517.

4. Craveț, G., 2014. Managementul stresului: cauzalități și interdependențe. ECOSTUDENT - Revistă de cercetare științifică a studenților economiști, 3, pp. 53-59.

5. Elias, H., Ping, W. S., \& Abdullah, M. C., 2011. Stress and Academic Achievement among Undergraduate Students in Universiti Putra Malaysia. Procedia - Social and Behavioral Sciences, 29, pp. 646-655. doi:10.1016/j.sbspro.2011.11.288.

6. EU-OSHA, 2014. Calculating the cost of work - related stress and psychosocial risks. European Risk Observatory Literature Review, Luxembourg: Publications Office of the European Union.

7. European Commission, 2010. Europe 2020. A European strategy for smart, sustainable and inclusive growth [Online], Available at: http://s9.ro/11yj. [Accessed 10 August 2019].

8. Eurostat, 2018. Young people on the labor market - statistics [Online]. Available at https://bit.ly/2UIwTWf. [Accessed 10 August 2019].

9. Fonkeng, C., 2018. Effects Of Job-Stress On Employee Performance In An Enterprise. A microfinance institution in Cameroon. [Online], Available at: https://www.theseus.fi/bitstream/handle/10024/145790/Celine\%20Fonkeng\% 20pdf.pdf?sequence=1\&isAllowed=y.[Accessed 25 August 2019].

10. Grigorievici, M., 2008. Arganizationae Pavedenie, Taganrog: TTI Iufu Taganrog.

11. Gujarati, D.N., 2004. Basic Econometrics, Fourth Edition. New York: McGraw-Hill.

12. Imtiaz, S., \& Ahmad, S., 2009. Impact Of Stress On Employee Productivity, Performance And Turnover; An Important Managerial Issue. International Review of Business Research Papers, 5(4), pp. 468-477. 
13. Jamal, M., 1984. Job stress and job performance controversy: an empirical assessment. Organizational behavior and human performance, 33(1), pp. 1-21. doi: 10.1016/0030-5073(84)90009-6.

14. Landy, F. J., \& Conte, J. M.,(2009). Work in the 21st century. An introduction to industrial and organizational psychology. Boston: McGraw-Hill.

15. Mirică, A., 2018. A Master Student Dilemma: To Work or To Study? Case Study on Romanian Economics Master Students. Proceedings of the 31st IBIMA Conference - Innovation Management and Education Excellence through Vision 2020, Milano, Italy, pp. 4875-4880.

16. Nyangahu, K. P., \& Bula, H. O., 2015. Relationship between Work Stress and Performance of Employees: A Case Study of Transit Hotel in Nairobi City County. Archieves of Business Research, 3(6), pp. 22-37. doi: 10.14738/abr.36.1538.

17. Oketch - Oboth, J. W., \& Okunya, L. O., 2018. The Relationship Between Levels of Stress and Academic Performance Among University of Nairobi Students. International Journal of Learning and Development, 8(4). doi:10.5296/ijld.v8i4.13840.

18. Opariuc-Dan, C., 2011. Statistică aplicată în științele socio-umane. Analiza asocierilor și a diferențelor statistice. Cluj: Editura ASCR.

19. Pitariu, H. D., Radu, I., \& Chraif, M., 2009. Selecția și evaluarea periodică a personalului. Supliment al Revistei managementul Resurselor Umane. ClujNapoca: Editura Asociației de Științe Cognitive.

20. Popa, I., Ștefan, S.C., Morărescu, C. \& Cicea, C., 2018. Research regarding the Influence of Knowledge Management Practices on Employee Satisfaction in the Romanian Healthcare System. Amfiteatru Economic, 20(49), pp. 553-566, doi:10.24818/EA/2018/49/553.

21. Popa, I. \& Ștefan, S.C., 2019. Modeling the Pathways of Knowledge Management Towards Social and Economic Outcomes of Health Organizations, International Journal of Environmental Research and Public Health, 16(7), 1114, doi:10.3390/ijerph16071114.

22. Rafidah, K., et al., 2009. Stress And Academic Performance: Empirical Evidence From University Students. Academy of Educational Leadership Journal, 13 (1), pp. 37-51.

23. Robinson, C., \& Schumacker, R.E., 2009. Interaction Effects: Centering, Variance Inflation Factor, and Interpretation Issues. Multiple Linear Regression Viewpoints, 35(1), pp. 6-11.

24. Saqib, M. \& Rehman, K.U., 2018. Impact of Stress on Students Academic Performance at Secondary School Level at District Vehari. International Journal of Learning and Development, 8(1), pp. 84-93, doi:10.5296/ijld. v8i1.12063.

25. Saunier, É., 2007. Et si on travaillait sans stress ! : Mode d'emploi pour retrouver confiance, sérénité et efficacité. Paris: Seuil Paris.

26. Zlate, M., 2007. Tratat de psihologie organizațional-managerială. București: Editura Polirom. 